\title{
Typisk vekstmønster for malignt pleuralt mesoteliom
}
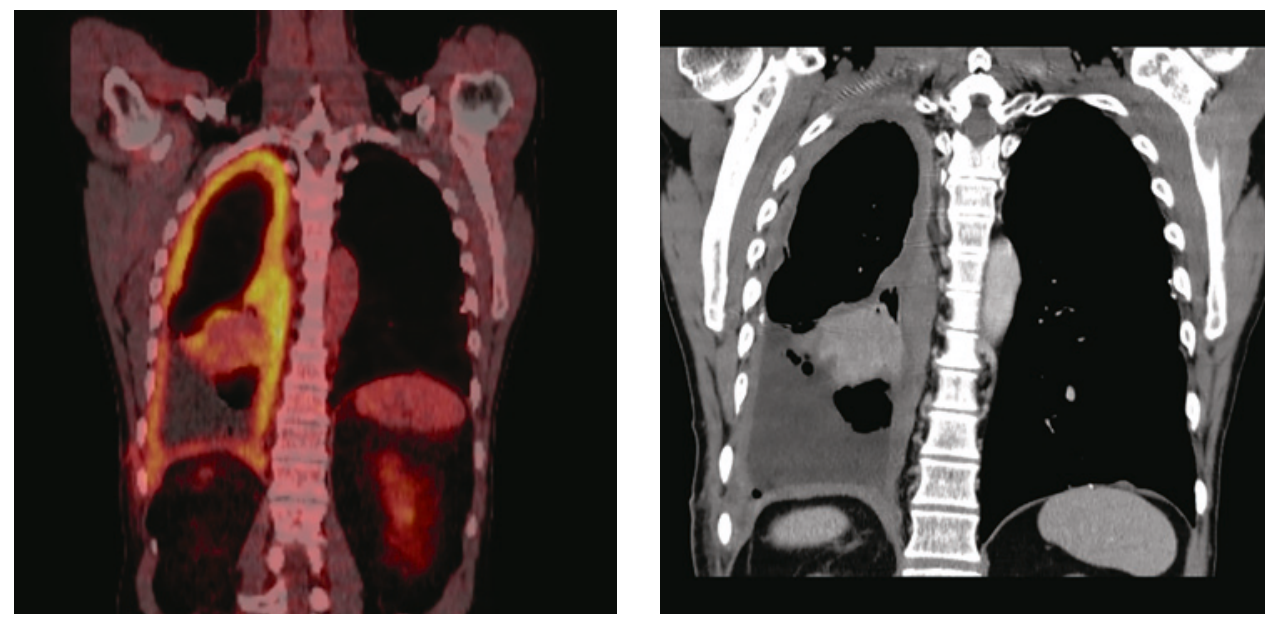

En mann i 60-årene ble utredet på bakgrunn av økende dyspné. Han hadde vært eksponert for asbest noen uker i 1970-årene, og hadde røykt fra 15 års alder. Det ble ikke funnet atypiske celler i pleuravæske. Diagnosen pleuralt mesoteliom ble fastsatt etter åpen pleurabiopsi. 18-fluorodeoksyglukose positronemisjonstomografi kombinert med computertomografi (18F-FDG PET/CT) ble rekvirert for å avklare om han kunne være kandidat for kirurgi.

18F-FDG tas opp i celler med høyt energibehov, som hjerte- og hjerneceller, betennelsesceller og maligne celler. Avbildning med $\mathrm{PET} / \mathrm{CT}$ viser til venstre opptak i et malignt pleuralt mesoteliom med typisk utbredelse langs mesotelkledde hinner, her langs høyre pleura, inkludert lappespaltene. Til høyre viser $\mathrm{CT}$ alene de strukturelle forandringene i detalj, men skiller dårligere mellom viabelt tumorvev og benigne forandringer, som atelektase.

18F-FDG PET/CT gir mulighet for mer nøyaktig bestemmelse av sykdomsutbredelsen enn CT alene. Dette utnyttes blant annet til å selektere pasienter med begrenset sykdom for kirurgi. Ved pleurafortykkelse av ukjent årsak kan undersøkelsen være til hjelp i vurderingen av hvorvidt fortykkelsen skyldes malignitet. På grunn av lav oppløselighet har undersøkelsen imidlertid begren- set sensitivitet for små eller tynne maligne lesjoner $(<5-8 \mathrm{~mm}$, avhengig av kamerateknologi). Tynne eller små maligne lesjoner i pleura inkludert i lappespalter kan derfor være PET-negative. Tykkere lesjoner uten opptak av 18F-FDG er mest sannsynlig benigne, selv om man må ta høyde for enkelte tumortyper som ikke tar opp stoffet.

Malignt pleuralt mesoteliom påvises årlig i Norge hos ca. 50-70 menn og ca. 15 kvinner (1). Sykdommen er vanligvis yrkesrelatert og knyttet til asbesteksponering - med latenstid 30-50 år. Prognosen er alvorlig, og under $10 \%$ er i live tre år etter diagnosen.

Hos denne pasienten ble utbredelsen vurdert å være for omfattende til at kirurgi var aktuelt. Han ble behandlet med palliativ kjemoterapi med målsetting livsforlengelse og symptomkontroll.

Pasienten har gitt samtykke til at artikkelen blir publisert.

\section{Arne Stenrud Berg}

arne.berg@vestreviken.no

Onkologisk poliklinikk

Drammen sykehus

\section{Ayca Løndalen}

Avdeling for radiologi og nukleærmedisin

\section{Odd Terje Brustugun}

Avdeling for kreftbehandling

Oslo universitetssykehus, Radiumhospitalet
Arne Stenrud Berg (f. 1972) er ph.d., spesialist i onkologi og overlege.

Forfatter har fylt ut ICMJE-skjemaet og oppgir ingen interessekonflikter.

Ayca Løndalen (f. 1962) er spesialist i nukleærmedisin og overlege.

Forfatter har fylt ut ICMJE-skjemaet og oppgir følgende interessekonflikter: Hun har mottatt honorar fra MSD Norge.

Odd Terje Brustugun (f. 1970) er dr.med., spesialist i onkologi og overlege og forsker ved Institutt for kreftforskning.

Forfatter har fylt ut ICMJE-skjemaet og oppgir ingen interessekonflikter.

Litteratur

1. Helland $\AA$, Solberg S, Brustugun OT. Incidence and survival of malignant pleural mesothelioma in norway: a population-based study of 1686 cases. J Thorac Oncol 2012; 7: 1858-61.

Mottatt 2.4. 2014, første revisjon innsendt 18.2. 2015, godkjent 22.4. 2015. Redaktør: Hanne Støre Valeur. 